\title{
Evaluation of nipple aspirate fluid as a diagnostic tool for early detection of breast cancer
}

Sadr-ul Shaheed ${ }^{1}$, Catherine Tait ${ }^{2}$, Kyriacos Kyriacou ${ }^{3}$, Richard Linforth ${ }^{2}$, Mohamed Salhab ${ }^{2}$ and Chris Sutton ${ }^{1 *}$ (D)

\begin{abstract}
There has been tremendous progress in detection of breast cancer in postmenopausal women, resulting in two-thirds of women surviving more than 20 years after treatment. However, breast cancer remains the leading cause of cancerrelated deaths in premenopausal women. Breast cancer is increasing in younger women due to changes in life-style as well as those at high risk as carriers of mutations in high-penetrance genes. Premenopausal women with breast cancer are more likely to be diagnosed with aggressive tumours and therefore have a lower survival rate. Mammography plays an important role in detecting breast cancer in postmenopausal women, but is considerably less sensitive in younger women. Imaging techniques, such as contrast-enhanced MRI improve sensitivity, but as with all imaging approaches, cannot differentiate between benign and malignant growths. Hence, current well-established detection methods are falling short of providing adequate safety, convenience, sensitivity and specificity for premenopausal women on a global level, necessitating the exploration of new methods. In order to detect and prevent the disease in high risk women as early as possible, methods that require more frequent monitoring need to be developed. The emergence of "omics" strategies over the last 20 years, enabling the characterisation and understanding of breast cancer at the molecular level, are providing the potential for long term, longitudinal monitoring of the disease. Tissue and serum biomarkers for breast cancer stratification, diagnosis and predictive outcome have emerged, but have not successfully translated into clinical screening for early detection of the disease. The use of breast-specific liquid biopsies, such as nipple aspirate fluid (NAF), a natural secretion produced by breast epithelial cells, can be collected non-invasively for biomarker profiling. As we move towards an age of active surveillance, home-based liquid biopsy collection kits are increasingly being applied and these could provide a paradigm shift where NAF biomarker profiling is used for routine breast health monitoring. The current status of established and newly emerging imaging techniques for early detection of breast cancer and the potential for alternative biomarker screening of liquid biopsies, particularly those applied to high-risk, premenopausal women, will be reviewed.
\end{abstract}

Keywords: Breast cancer, Biomarkers, Proteomics, Liquid biopsy, Nipple aspirate fluid (NAF)

\section{Background}

Breast cancer is a global health problem affecting women, and to a lesser extent men, and constituted $25 \%$ of all cancers in 2012, with 883,000 cases each year in less developed and 794,000 cases in more developed regions of the world [1]. There were 458,000 breast cancer-related deaths worldwide (269,000 in developing and 189,500 in

\footnotetext{
*Correspondence: c.w.sutton@bradford.ac.uk

1 Institute of Cancer Therapeutics, University of Bradford, Bradford, UK Full list of author information is available at the end of the article
}

developed countries) in 2008 [2]. Furthermore, it is the leading cause of death in the world among women aged 40-59 years, and in premenopausal women, incidence and mortality has increased in South America, Central America and Africa [3, 4]. Analysis of the SEER (19882003 Surveillance, Epidemiology and End Results) Program data, comparing women less than 40 years old with those more than 40 years old, indicated that although they only constituted $6.4 \%$ of the study, they were more likely to die from breast cancer [5]. Limited breast health 
awareness and access to screening has a significant impact on the ability of health services to diagnose and treat the disease at a sufficiently early stage, and in many cases, by the time the patient presents at clinic, the cancers have already become aggressive. This problem is not unique to less developed countries as deaths also reached an all-time high during 2010 in the UK for women under 50 years old. The risks associated with breast cancer are well established and include genetic predisposition [6, 7], reproductive factors (menarche, parity, lactation, menopause) [8-10], environment (chemical exposures, drugs, infectious agents) [11, 12], demographic factors (age, race, sex, socio-economic status, geographic location) [13], systemic factors (epigenetics) [14] and lifestyle (smoking, alcohol use, diet, obesity, exercise) [15].

The major risk factor is age and the majority of breast cancer cases occur in women after menopause. However, the correlation of risk with reproductive, environmental and lifestyle parameters, strongly indicate the origins of many breast cancers are concealed by a prolonged period of dormancy that only manifest in later life [16]. Lifestyle parameters are unique among these factors, since they can be modified and consequently fall within the scope of the individual to proactively reduce these risks by taking preventative measures, whereas genetic, reproductive, environmental and demographic factors are beyond the control of most individuals. Women at highest risk, accounting for $5-10 \%$ of cases, are those who inherit gene mutations, and have 10- to 30-fold higher chance of developing breast cancer during their lifetime compared to the general population. Genetic predisposition can be identified initially through investigation of family history of the disease and confirmed by screening for predictive mutations associated with specific high-penetrance genes, such as the BRCA1, BRCA2, TP53 and PTEN genes [6].

The emergence of genomic technologies in the last 20 years has had a major impact on understanding disease stratification in breast cancer, which is not only providing insights on how the disease progresses, but clinical direction in targeted treatment and prediction of outcome. There are currently 5 main phenotypes, Luminal A, Luminal B, Her2, basal-like and Claudin-low, but further stratification can be anticipated [17]. At the simplest level, each phenotype is defined by expression or absence of three cell surface proteins, estrogen receptor $(\mathrm{ER})$, progesterone receptor (PR) and human epidermal growth factor receptor (HER2). These phenotypes also correlate with normal mammary cellular development [18]. Claudin-low and Basal-like types, originating from breast stem and progenitor cells, respectively, constitute the majority of triple negative breast cancers (TNBC), which have a particularly poor prognosis, no targeted treatment, high chance of re-occurrence and poor overall survival. TNBC is also strongly associated with BRCA1/ BRCA2 induced cancer [19] and with obesity in premenopausal women [20].

Because of extensive epidemiological and etiological studies, it is becoming easier to identify those women who are at highest risk of breast cancer. Unfortunately, none of these measures can predict when breast cancer will occur. Regular screening for the appearance of breast cancer, which is recommended for women reaching menopause, is even more critical in high risk women during their reproductive years. There are various screening modalities, each with advantages and disadvantages (Table 1), making them sub-optimal for more frequent monitoring as required by this group. As a consequence, the major means of preventative intervention for these women can be extreme, involving elective pre-symptomatic surgery to remove both breasts. Therefore, new and more sensitive approaches are required to detect the earliest stages of the disease, which will enable less drastic means of intervention. Initially, we review the various established screening methods, to understand their limitations.

\section{Breast cancer detection}

\section{Self-examination}

Self-examination encourages women to be involved in active surveillance of their own breast health, increasing awareness of changes, both natural and abnormal. It provides an effective way for early detection of up to $50 \%$ tumours and improves discovery of other breast-related diseases without involving specialist equipment or professional health care assistance [21]. However, the prevalence of breast self-examination is still low, particularly in educationally-deprived and developing countries [22].

\section{Mammography}

Mammography is by far the most common approach for screening breast cancer. In Europe, women aged 50-70 are invited for breast screening every 2-3 years, while in US annual mammograms are recommended from 50 to 74 years equating to nearly 39 million images in 2014 . Women who have an increased risk of developing breast cancer, but are too young to join national screening programs, are offered annual screening using mammography and magnetic resonance imaging (MRI) based on a riskbenefit decision. Sensitivity of mammography can vary from almost $100-40 \%$ dependent on tissue composition $[23,24]$, and positive association for prediction of disease is only $50 \%$. False-positive rates in breast cancer screening are a significant limitation, as high call-back rates and unnecessary biopsies result in increased cost, radiation exposure, and patient anxiety during re-screening $[25$, 
Table 1 A semi-quantitative comparison of liquid biopsies that have been used for breast cancer biomarker discovery

\begin{tabular}{|c|c|c|c|c|c|c|c|c|}
\hline Liquid biopsy & Volume & Accessibility & Discomfort & $\begin{array}{l}\text { Reference } \\
\text { sample* }\end{array}$ & $\begin{array}{l}\text { Sample } \\
\text { preparation }\end{array}$ & $\begin{array}{l}\text { Biomarker } \\
\text { concentration }\end{array}$ & $\begin{array}{l}\text { Patient led } \\
\text { collection }\end{array}$ & Convention \\
\hline Plasma & ++ & +++ & +++ & $x$ & ++++ & ++ & $x$ & +++++ \\
\hline Urine & +++++ & +++++ & + & $x$ & +++ & + & $\sqrt{ }$ & ++++ \\
\hline Saliva & +++ & +++++ & + & $x$ & ++ & + & $\sqrt{ }$ & +++ \\
\hline Ductal lavage & + & + & ++++ & $\sqrt{ }$ & + & +++++ & $x$ & + \\
\hline $\begin{array}{l}\text { Random } \\
\text { Periareolar } \\
\text { Fine Needle } \\
\text { Aspiration }\end{array}$ & + & + & +++++ & $\sqrt{ }$ & ++ & +++++ & $x$ & + \\
\hline $\begin{array}{l}\text { Nipple Aspirate } \\
\text { Fluid }\end{array}$ & + & $+++(+)$ & ++ & $\sqrt{ }$ & + & +++++ & $\sqrt{ }$ & ++ \\
\hline+ & Small & Invasive & $\begin{array}{l}\text { No discomfort/ } \\
\text { no distress }\end{array}$ & & $\begin{array}{l}\text { Extensive } \\
\text { processing } \\
\text { required }\end{array}$ & Low & & $\begin{array}{l}\text { Infrequent use } \\
\text { for biomarkers }\end{array}$ \\
\hline+++++ & Large & Easily available & Painful/stressful & & $\begin{array}{l}\text { Limited pro- } \\
\text { cess required }\end{array}$ & High & & $\begin{array}{c}\text { Frequent use for } \\
\text { biomarkers }\end{array}$ \\
\hline
\end{tabular}

(+) Accessibility enhanced by oxytocin nasal spray

*Comparison of healthy and disease sample pairs provides an internal reference

26]. Over a period of 20 years, based on 7 trials of more than 600,000 women, screening was shown to reduce breast cancer mortality by $15 \%$ however over-diagnosis was estimated at $29 \%$ [27, 28]. In particular, mammography is approximately $10-15 \%$ less sensitive in women under 50 than in postmenopausal women [29]. Women in their 40s screened within the UK Age Trial had a 5\% risk of a false-positive result at their first screen [30] and a random clinical trial of 161,000 women showed that women aged 39 onwards did not significantly reduce their risk of dying from breast cancer within 5-15 years [31].

The continuing development of mammography, including digitisation with improved resolution (full field digital mammography), has strengthened its position as the Gold standard for screening but still requires the presence of a substantial mass in the breast for a diagnosis $[32,33]$. Many breast tumours may have already metastasised before detection by mammography. Equally, a mammogram cannot always distinguish between benign micro-calcifications associated with low risk DCIS (therefore may not require surgical treatment) and higher risk DCIS that will progress to a malignant invasive tumour [34]. Even when supported by histopathological screening of core biopsies, there has been a tendency to over-diagnose and over-treat DCIS cases [35]. Consequentially, some women receive a false-positive diagnosis resulting in unnecessary surgery to remove the lump or whole breast. Radiation exposure has also been shown to contribute to increased incidence of breast cancer, particularly in high risk populations, resulting in heart disease induced by breast or cell wall radiotherapy [23].
One of the challenges for imaging methods is breast tissue density, which is higher in younger women, making their mammograms harder to interpret, whereas postmenopausal women with extensive fatty breast tissue or ductal atrophy are more likely to have an accurate diagnosis [36]. Breast density is strongly associated with tissue composition (collagen, epithelial cell and nonepithelial cell content, glandular area), genetic influences and hormonal regulation (prolactin, IGF-1). Furthermore, mammographic density is positively associated with alcohol consumption, smoking in post-menopausal women and with breast cancer [36, 37]. It is possible to quantitatively measure breast density using established and specialised imaging modalities in combination with bespoke algorithms [38], however this strategy has not been widely accepted.

\section{Other imaging techniques}

Digital breast tomosynthesis (DBT) is a relatively new screening approach, which uses an X-ray beam in an arc around the breast to provide a $3 \mathrm{D}$ reconstruction of the tissue. In a comparison of DBT with digital mammography for 2666 breast lesions, the former had improved performance (sensitivity and specificity of 90 and $79 \%$, respectively) compared to the latter ( 89 and $72 \%$, respectively) [39], but was also subject to the same limitations incurred by breast density. There are fewer recalls with DBT compared to digital mammography, particularly in younger women, and although approved by the Food and Drug Administration for breast screening, it is not widely available [40]. Ultrasonography, using high-resolution linear transducers, is readily accessible, similar in cost to 
mammography and moderately improves cancer detection, but has lower specificity, lower positive predictive value and was similarly obfuscated by tissue density [41].

Contrast-enhanced MRI, by comparison is not limited by breast density, nor does it use ionising radiation. In a review of 11 studies comparing MRI with digital mammography, the former achieved 94\% sensitivity, but identified few cases of cancer in addition to those discovered by digital mammography alone [42]. Furthermore, MRI exhibited relatively low specificity, was time consuming, had limited accessibility and high cost to run. Positron Emission Tomography with computer tomography (PET$\mathrm{CT}$ ) uses gamma-radiated emitting fluorine-18 fluorodeoxyglucose (FDG), a glucose analogue, injected into arm veins to accumulate in areas of high metabolic activity, such as tumours, and is then detected using a PET-CT $\mathrm{x}$-ray scanner [43]. Sensitivity of PET-CT ranged from 71 to $90 \%$, which was improved further when combined with mammography, but results were affected by breast size [44]. However, PET-CT is more often used to assist surgery to remove diseased tissue rather than as a front line routine screen for initial detection of breast cancer. Wave elastography uses ultrasound or MRI techniques to measure tissue stiffness, which is positively associated with a tumour mass compared to normal tissue. The application of shear wave elastography, which uses the force of acoustic radiation produced by an ultrasound beam, demonstrated improved sensitivity and specificity [45]. Electrical impedance scanning is another modality under development for breast cancer detection especially in young women with dense breasts, which is based on lower electrical impedance in malignant tumours compared to the surrounding normal tissue [46]. Recent technological advances have facilitated dynamic thermal analysis of the breast by recording of circadian rhythm variations and analysing the recorded data using highly sophisticated statistical algorithms, but this approach currently suffers from high false positive rates [47]. Although showing great promise, none of these innovative imaging approaches are in a position to replace mammography as the mainstream approach to routinely detect breast cancer and most importantly cannot differentiate between benign and malignant growths.

\section{Biomarkers}

There have been extensive studies to identify breast cancer biomarkers, but with varying degrees of success. Genomics has already stratified the disease to identify high risk individuals and histopathological approaches are used to determine ER, PR and HER2 expression, helping to direct clinical intervention. Indeed, microarraybased technologies for routine prognostic screening of multigene signatures (for example, 70-gene MammaPrint for tumour aggressiveness/chemotherapy requirement/ metastatic prognosis [48], Celera 14-gene for metastasis score [49], Oncotype-DX 21-gene signature for measuring risk of re-occurrence [50], and 76-gene Veridex signature for tamoxifen therapy benefit [51]) have been invaluable in supporting treatment of ER/PR positive breast cancers. However, the identification of a specific biomarker for the detection of breast cancer at the earliest stage that can be analysed in biopsies, has so far evaded the diagnostic industry. Proteins and metabolites have been discovered which were increased in malignant tissues compared to normal, but were subsequently found to be diluted beyond the level of detection in plasma or urine, or were found not to be specific for breast cancer. These have been reviewed extensively elsewhere and will not be covered here [52]. In addition, depletion methods may be required to remove the most abundant proteins such as albumins and immunoglobulins from plasma, prior to analysis, which can result in losses and further reduced sensitivity. It is therefore not surprising that a comprehensive review of breast cancer biomarkers in 2007 by the Update Committee of the American Society of Clinical Oncology failed to recommend any of the most promising candidates, including blood levels of CA 15-3 and CA 27.29 (both forms of mucin-1) for diagnosis, detection of recurrence, decisions on therapy or metastasis, or circulating truncated extracellular HER2 for detection of breast cancer [53]. Clearly, accessing tissue biopsies to look at tumour-associated biomarkers, where they are most concentrated, on a regular basis is not practical, though most of the accepted biomarkers ER, PR, HER2, urokinase-type plasminogen activator (UPA) and plasminogen activator inhibitor 1 (PAI-1) are currently analysed in tissues by immunohistochemistry or ELISA [53]. Hence, the challenge remains, how to provide a low cost, safe, simple, sensitive and specific method for detecting breast cancer, early enough, avoid unnecessary overtreatment and surgery? In this context, molecular diagnostic approaches for the early detection of breast cancer remain largely untapped.

\section{Breast-specific liquid biopsies}

By far the best liquid biopsies (or biofluids) for developing a screening diagnostic are those readily accessible and in close proximity to the disease area, such as saliva for oral cancers or urine for bladder or renal cancer (Table 2). In this respect, various methods have been developed to access ductal liquids that are associated with cells that are the origin of the majority of breast cancers. We present, a case for using nipple aspirate fluid (NAF) for routine breast cancer screening, but initially, review the various breast-associated fluids that have been studied, with a specific emphasis on proteomics characterisation. 


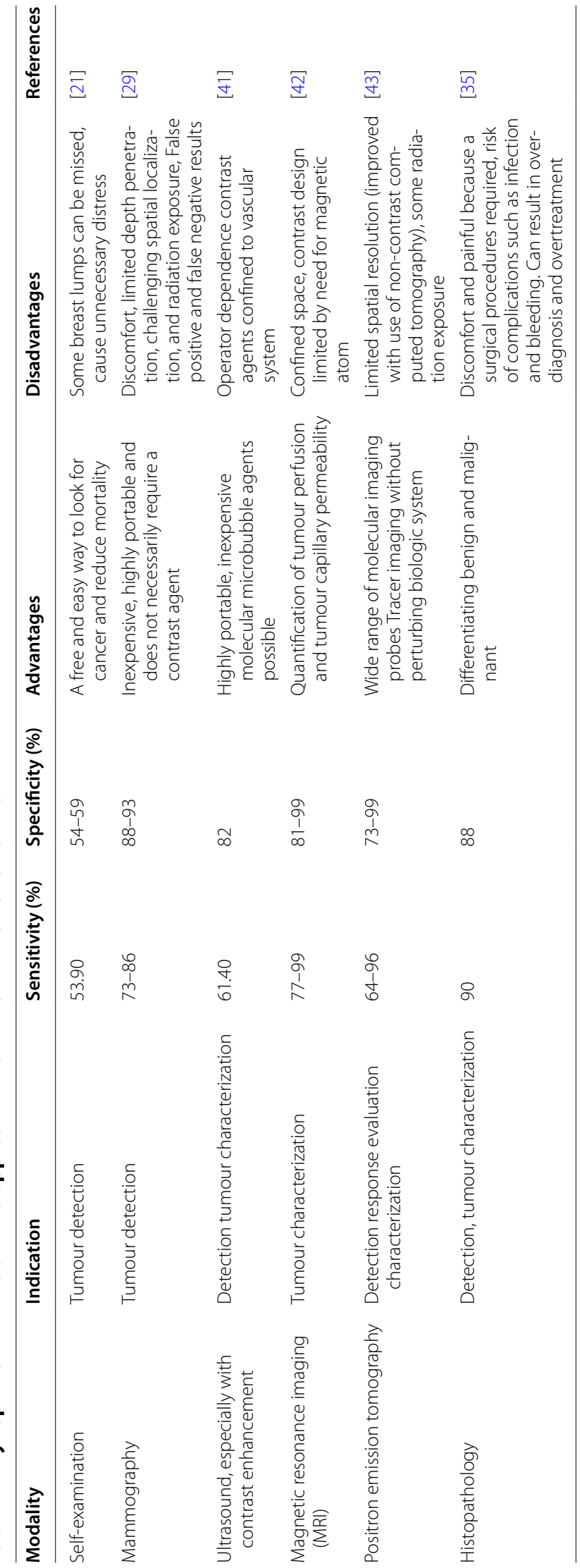




\section{Milk and colostrum}

There have been a number of proteomics studies on milk purely from a functional perspective, unrelated to cancer, with a recent study identifying up to 1600 proteins $[54,55]$. Colostrum, produced 2 or 3 days prior to lactation, preparing the infants digestive system for milk as a food source and immunisation against infection, has also been characterised. In a study of 100 samples using 2D liquid chromatography mass spectrometry (LC MS), 151 proteins were identified after immunodepletion (to remove the most abundant proteins), including 83 found in colostrum but not milk [56]. Although available in useful volumes for analysis, the period of production during the reproductive phase of life is relatively narrow and in most cases will not overlap with breast cancer development. Consequently, there has been very little research on proteomic profiling of breast cancer in milk or colostrum because of the relatively small proportion of women in which the disease and postnatal breast-feeding, coincide. Nevertheless, Schneider et al. were able to profile samples from a small cohort and identified proteins that were uniquely present in milk from women diagnosed with breast cancer [57].

\section{Breast cyst fluid}

Several epidemiological and prospective studies indicate there may be a relationship between cystic breast disease and cancer [58]. There are two types of breast cyst (Type I or apocrine cysts and Type II) differentiated on the basis of morphological and cellular characteristics. Apocrine cysts differ from Type II cysts in having a higher $\mathrm{K}^{+} / \mathrm{Na}^{+}$ratios while Type I cysts are more strongly related with breast cancer [59]. According to Mannello et al., more than 100 studies have identified 81 proteins in breast cyst fluid, with the major components identified as albumin, prolactin inducible protein, $\mathrm{Zn}-\alpha_{2}$-glycoprotein, and apolipoprotein D [59]. A 2-D gel electrophoresis/mass spectrometry study on apocrine macrocyst fluid identified that 15-hydroxyprostaglandin dehydrogenase and 3-hydroxymethylglutaryl-CoA synthase were associated with cysts and tumour tissue and were absent in matched normal tissue [58].

\section{Ductal lavage (DL)}

Ductal lavage (DL) is a non-surgical breast epithelial sampling procedure that was developed to identify high risk breast cancer women and to detect malignant lesions in breast epithelial cells. In the DL procedure a microcatheter is cannulated to the ducts, infused by a saline solution, and then aspirated by a suction device to collect cells from the lining of ducts. More cells are acquired through ductal lavage than from nipple aspiration [60], and liquid biopsies can be obtained from women that do not yield fluid by passive nipple aspiration or discharge or from breast massage. Ductal lavage containing sufficient cells was collected from 31 women (out of 36 volunteers) diagnosed with breast cancer and analysed for atypical cytology as a possible diagnostic indicator, however only $13 \%$ produced a significant positive indication [61]. A separate study of 30 samples found that $23.3 \%$ of women had atypical lavage cytopathology; interestingly these women had normal mammogram screening of breast, indicating the potential for improved sensitivity [62]. The isolation of cells from ductal lavage opens up the opportunity for applying molecular biology approaches. Multiplex methylation-specific polymerase chain reaction (QM-PCR) was used to quantitate cumulative gene promoter hypermethylation in multiple genes, which are markers for breast cancer, and found to double the sensitivity of detection of cancer cells compared with cytology [63]. An attempt to identify biomarkers of tamoxifen action (e.g. changes in expression of estrogen receptor $\alpha$, Ki-67 and cyclooxygenase-2) in ductal lavage, however, found no significant cytological or molecular variations in patients [64]. Recently, an improved method of ductal aspiration, collecting multiple aliquots, considerably increased the cell recovery with $45 / 50$ subjects yielding more than 1000 cells and $50 \%$ of those producing more than 20,000 cells with $80-100 \%$ epithelial cell purity. This provided genomic DNA, RNA and miRNA samples for analysis however, to date only qualitative observations of the molecular profiles have been reported [65]. Do Canto et al. identified more than 700 miRNAs from ductal lavage from women with unilateral breast cancer, of which 17 were differentially expressed between tumour and paired normal samples and have previously been associated with tumorigenic processes and signalling pathways for invasiveness and metastases [66]. In a related study, the metabolomic profiles of ductal lavage of 43 women with breast cancer was acquired [67]. From a total of 2098 compounds (detected in both positive and negative ion mode with a QTOF mass spectrometer), a signature of 21 metabolites (including $N$-acetyl-DL-tryptophan, $N$-linoleoyl taurine, trans-2-dodecenoylcarnitine and specific phospholipid isoforms) was determined to provide a ROC Curve of $90.7 \%$ sensitivity in diagnosing breast cancer. However, ductal lavage can cause considerable discomfort which has prevented widespread clinical use [68]. Furthermore, the process of flushing the ducts, results in dilution of the protein components and hence reduced sensitivity for biomarker profiling.

\section{Random Peri-areolar Fine Needle Aspiration (RPFNA)}

RPFNA, developed by Dr. Carol Fabian in 1998, provides a snap-shot of the breast by sampling cells from the entire breast of asymptomatic women [69, 70]. The major 
advantage of RPFNA is that it can be performed in the majority of women and the cell yields vary from 72 to $85 \%$, considerably higher than ductal lavage. [71]. After anesthetizing the breast with $1 \%$ lidocaine, five needle aspirations are made on the lateral breast site and four from the middle skin of each. The aspirated fluid consists of epithelial, immune, stromal and adipose cells [70].

A clinical trial of 480 women indicated that RPFNA increased detection of cytological atypia associated with breast cancer in high-risk women (based on family history, a prior diagnosis and precancerous biopsy) [70]. Of the cohort, 20 women subsequently developed breast cancer after 45 months (7 DCIS and 13 invasive), indicating a promising potential for very early diagnosis. RPFNA was used for a chemoprevention study of alpha-difluoromethylornithine (DFMO) in 119 high-risk women, but found no change in cytology or other RPFNA-based molecular markers such as expression of proliferating cell nuclear antigen, p53 or epidermal growth factor receptor [72]. A proteomic microarray study found that up to 60 phosphoproteins can be verified in triplicate from 5000 to 10,000 micro-dissected RPFNA epithelial cells, suggesting the possibility to track signalling pathways in order to understand the molecular changes occurring in mammary carcinogenesis [73]. The heterogeneous nature of the cell populations being tested for specific molecular markers and considerable discomfort to obtain the samples, are key limitations of the RPFNA approach. Furthermore, the difficulty in reproducing the method may preclude a role in screening of high-risk women that involves repeated harvesting of material.

\section{Nipple aspirate fluid (NAF)}

The breasts of adult non-lactating women secrete small volume of fluid, called "nipple aspirate fluid" (NAF, which here also includes spontaneous nipple discharge) into the breast ducts [74]. The research presented within this section relates to nipple secreted fluids collected by noninvasive methods, either passive discharge or by use of massage or pumps, differentiating them from the invasive approaches previously described (ductal lavage RPFNA, etc.). There have been a series of seminal reviews outlining the importance of NAF for diagnosing breast cancer [75-78], however, the current review aims to promote the progression that has been achieved through the application of 'omics' strategies. The fluid passes down the main ducts and ampullae through alveolar glands of breast, from which it enters the lymphatic and blood circulation [79]. Under normal conditions, the breast fluid cannot escape from the nipple because the ducts are blocked by viscous and dried-up secretions or because of the presence of constrictive bands of smooth muscle and keratinized epithelium [79]. To maintain stable physiology of the breast, an equilibrium exists between fluid secretion and re-absorption. Several factors are associated with NAF production; age, ethnicity, early menarche, history of lactation, high dietary fat consumption and dietary intake of lactose [80]. There is also a direct relationship between ear wax and NAF because both are produced by modified apocrine glands (ceruminous and mammary, respectively). Women with wet ear wax yield more NAF, compared to women with dry ear wax [81]. Premenopausal women with lactation experience, aged 30-50 years and who had early onset of menarche produce more NAF compared to those who have not had children [80]. A study of 25 to 49-year-old premenopausal nulliparous women found that proportionately, Asian-descendant women were less likely to produce NAF compared to White American women [53].

NAF collection has been achieved with varying degrees of success dependent on the method and the practitioner and, in some cases, has deterred researchers from further investigation. Electronic and manual breast pumps (normally used for lactation), massage, warming and combinations of each have been used to acquire NAF samples [82]. Most promising has been the use of oxytocin nasal spray which helps the release of already existing fluid in the ducts increasing collection in $95 \%$ of patients and volunteers [83].

NAF is a rich source of molecular and cellular information. Indeed, in a composite study of published data on NAF cell content, cellularity or proliferative epithelial disease was observed to be an independent risk determinant for breast cancer development [84]. This reflects the increased exfoliation of epithelial cells lining the ducts and lobules as they proliferate through hyperplasia, in situ carcinoma and invasive carcinoma with disease progression [85]. The released cells not only increase in number but also change in appearance, exhibiting morphological differences (irregularly shaped nuclei, rough endoplasmic cisternae and well-developed Golgi complexes associated with nucleic acid and protein synthesis) [86].

NAF is also composed of a variety of endogenous substances such as lactose, proteins, fatty acids, hormones (estrogens, androgens, progesterone), sterols, but may also contain exogenous substances such as nicotine and cotinine from cigarette-smoking [74]. The colour of NAF varies from clear to brown, bloody, black, pale yellow, dark yellow, white or green [87], and is associated with the concentration of cholesterol, estradiol, estrone, cholesterol epoxides and peroxidated lipids [88]. NAF has also been shown to contain microorganisms and the ductal microbiome was distinctly different from that of the nipple and areolar skin [89]. In addition, a comparison of 6 breast cancer patients (contralateral sample) 
with 6 healthy controls (both breasts) showed variations in particular microbe genus incidence, indicating a potential role in the disease.

The colour of NAF is more an epidemiological factor than an indicator of the risk of breast cancer, however one study found that women have a higher risk of breast cancer with bloody or brown nipple discharge, compared to those which were white, cream, yellow or green [90]. Another study of 327 women found that the frequency of red or brown colour was increased with progression of disease from pre-cancer to cancer and surgical biopsy has more influence on NAF colour compared to needle biopsy [91].

NAF production, nutritional aspects and estrogen level have been found to be related to breast cancer risk. A large scale study of 1496 participants (1347 white and 153 black women) found a positive association between higher dietary fat and NAF secretion in the group aged 30-44 years [92]. As obesity is associated with a high fat diet and is a major risk factor for breast cancer, correlation of fat intake, and NAF production and composition may be helpful for breast cancer prevention and prognosis [93]. A link between lactose and soy intake has also been reported, however contrary results from a randomized crossover trial discovered no influence of soy on NAF volume and circulating estrogen level [94]. On the other hand, a fruit-and-vegetable diet was inversely related with NAF production while decreasing the circulating hormone concentration [95]. The concentration of micro-nutrients, such as carotenoids and soy isoflavones in NAF, was also related to dietary intake [96].

\section{NAF biomarkers}

In order to place the 'omics' approaches to global analysis of molecular events in NAF profiling, into perspective, it is important to appraise the extensive research on specific biomarker targets that has been undertaken in NAF (Table 3). Based on the differential levels of testosterone in serum from pre- and postmenopausal women, Sauter et al. measured testosterone levels in NAF samples and found it would be a suitable biomarker to predict breast cancer risk [97]. A separate study, which measured the level of free and albumin-bound testosterone in NAF, found high levels of the former in premenopausal women with breast cancer [98].

Thomsen-Friedenreich (TFr) and Tn antigens are aberrant O-linked mono- (GalNAc) or disaccharides (Gal-GalNAc) found on cell surface glycoproteins and associated with the progression of numerous cancers including bowel, skin, prostate and breast. A study of the expression of TFr and Tn antigens found that NAF of $90 \%$ breast cancer patients have high content of TFr and Tn compared to normal NAF, because both antigens are
Table 3 A summary of putative biomarkers and their biological function that have been identified in nipple aspirate fluid

\begin{tabular}{|c|c|c|}
\hline Biomarker (s) & Characteristics & References \\
\hline $\begin{array}{l}\text { Prostate specific antigen } \\
\text { (PSA) }\end{array}$ & $\begin{array}{l}\text { Inversely proportional to } \\
\text { disease stage, size of tumour, } \\
\text { node status and distant } \\
\text { metastases }\end{array}$ & [102-104] \\
\hline $\begin{array}{l}\text { Thomsen-Friedenreich } \\
\text { (TFr) and Tn antigens }\end{array}$ & $\begin{array}{l}\text { Predictive for the presence of } \\
\text { breast cancer or atypia }\end{array}$ & {$[99,100]$} \\
\hline Testosterone & $\begin{array}{l}\text { Predictive in postmenopausal } \\
\text { women only }\end{array}$ & {$[97,98]$} \\
\hline $\begin{array}{l}\text { Superoxide dismutase } \\
\text { (SOD-1) }\end{array}$ & $\begin{array}{l}\text { Involved in cancer initiation } \\
\text { and progression by ROS } \\
\text { related damages }\end{array}$ & {$[105]$} \\
\hline Protein DJ-1 & $\begin{array}{l}\text { mRNA level increased but pro- } \\
\text { tein level decreased in tissue }\end{array}$ & {$[106]$} \\
\hline Cytokines/chemokines & $\begin{array}{l}\text { High level of pro-inflammatory } \\
\text { C-C and CXC chemokines. }\end{array}$ & {$[107]$} \\
\hline $\begin{array}{l}\text { Plasminogen activator } \\
\text { inhibitor-1 (PAl-1), } \\
\text { urokinase-type plasmi- } \\
\text { nogen activator (UPA) }\end{array}$ & $\begin{array}{l}\text { Promotes breast cancer inva- } \\
\text { sion and metastasis }\end{array}$ & {$[110,111]$} \\
\hline $\begin{array}{l}\text { Serotransferrin protein } \\
(\mathrm{TF}) \text { and ferritin (FTN) }\end{array}$ & Proliferation of cancer cells & [109] \\
\hline C-reactive protein (CRP) & $\begin{array}{l}\text { Serum biomarker for metastasis } \\
\text { of different type of cancers }\end{array}$ & {$[112,113]$} \\
\hline
\end{tabular}

present on the surface of epithelial cancer cells and lipids [99]. A recent study of 137 women found that the concentrations of TFr and Tn antigens were lower in women with benign disease, compared to those with atypical hyperplasia. They also found that the expression of TFr is more predictive for the presence of breast cancer or atypia compared to Tn [100].

Proteins are major constituents of NAF with concentrations that can be higher than plasma, up to $170 \mathrm{mg} /$ $\mathrm{ml}$. NAF, most importantly, is enriched for proteins originating from epithelial cells lining the duct [101], some of which have been evaluated as potential biomarkers of breast cancer. Prostate specific antigen (PSA), also known as kallikrein-3 (KLK3), first identified in seminal plasma and prostatic tissue, produced by the epithelial cells lining the acini and ducts of prostate gland, has also been identified in female breast tumours [102]. A study of NAF found that women with no risk factors or family history of breast cancer had high levels of PSA, but women with precancerous or invasive cancer had reduced levels [103]. Furthermore, PSA levels were inversely proportional not only to disease stage, but also tumour size, node status and distant metastases [104].

The concentration of superoxide dismutase $[\mathrm{Cu}-\mathrm{Zn}]$ (SOD-1) in NAF was decreased in breast cancer patients compared to healthy individuals [105]. SOD-1 is involved in cancer initiation and progression caused by reactive 
oxygen species-related damage. Therefore, it was proposed that measuring the concentration of SOD-1, a key antioxidant enzyme in breast microenvironment, may be helpful to differentiate between the normal and tumour breast.

The expression of anti-oxidant oncogene DJ-1 mRNA is increased in ductal carcinoma tissues but the opposite effect was observed at the protein level, where expression is decreased and contrarily was elevated in blood of breast cancer patients. A study on NAF collected from 136 patients identified high levels of DJ-1 protein in NAF from breast cancer patients, but low levels in benign papilloma cases [106].

NAF samples collected from non-cancer and cancer women for cytokine profiling found no difference in anti-inflammatory cytokines (IL-4, IL-9, IL-10 and IL-13), pro-inflammatory cytokines (IL-2 and interferon- $\gamma$ ), immuno-modulatory interleukins (IL-5, IL-7) or chemokines (RANTES, IP-10, eotaxin). However, NAFs from cancer patients with high levels of aluminium in the breast microenvironment, had higher concentrations of pro-inflammatory cytokines (IL-1 $\beta$, IL-6, IL-12 p70, and TNF- $\alpha$ ), and C-C (MCP-1 and MIP-1 $\alpha$ ) and CXC-type chemokines (IL-8) compared to those cancer patients with low aluminium levels. This indicated a significant correlation between proinflammatory cytokines (IL-6), monocyte/macrophage chemo-attractant chemokines (MIP- $1 \alpha$ and MCP-1), oxidative stress and aluminium content in cancerous NAFs [107].

Cancer cells contain high levels of transferrin (TF) and ferritin (FTN), as well as higher expression of TF receptors compared to normal cells, suggesting proteins involved in $\mathrm{Fe}$ metabolism play important role in the proliferation of breast cancer cells [108]. A study of NAF collected from 66 women found that cancer patients (particularly postmenopausal) have high levels of TF and FTN, compared to healthy women [109]. Hence, measuring soluble FTN and TF in NAF may help the early identification of women with increased breast cancer risk, even though these proteins are not expressed by local breast tissues.

Plasminogen activator inhibitor-1 (PAI-1), normally found in plasma, promotes breast cancer invasion and metastasis by directly inhibiting proteases, suggesting that excessive plasmin proteolysis may inhibit the assembly of tumour blood vessels, modulation of cell adhesion and the stimulation of cell proliferation [110]. Significantly higher levels of UPA and PAI-1, along with the Thomsen-Friedenreich antigen, have been reported in NAF of women with cancer, with the former more predictive for postmenopausal and the latter more indicative for premenopausal patients [111].
C-reactive protein (CRP) is already a developed serum biomarker for metastasis of various cancers including advanced stages of breast cancer [112]. Elevated CRP levels in ductal epithelia of the breast are an indicator of inflammatory processes associated with an early benign stage. A study on 59 samples found that CRP in NAF was positively related to the Gail model for breast cancer risk [113].

\section{NAF proteomics}

Proteomics approaches for characterising NAF has previously been reviewed by Mannello et al. [114], since which there has been rapid advancement in mass spectrometric technology and the development of new quantitative strategies. On the basis of the unique characteristics of NAF, proteomic analysis should serve as a useful approach to understand the physiology of breast cancer and for biomarker discovery. However, early proteomic profiling of NAF samples collected from cancerous and non-cancerous breasts of patients using surfaceenhanced laser desorption ionization mass spectrometry (SELDI-MS), revealed no significant differences in the SELDI-MS peak profiles [115]. Use of more powerful separation techniques started to reveal differences. Varnum et al. identified 64 proteins in immune-depleted NAF samples, using an ion trap mass spectrometer, among which 15 had previously been reported to be altered in tumour tissue and serum from women with breast cancer, including osteopontin and cathepsin D [116]. Twodimensional PAGE separation of proteins, followed by in-gel digestion with trypsin and matrix-assisted laser desorption ionization time-of-flight mass spectrometer (MALDI-TOF) analysis, identified 41 components in NAF [117]. Among these, levels of prolactin-inducible protein, apolipoprotein $\mathrm{D}$, and $\alpha_{1}$-acid glycoprotein, were observed to be changed in cancer NAF samples. Further validation by ELISA, indicated that expression of these proteins correlated with pre-/postmenopausal status and cancer stage. Pawlik et al. [118] used Isotope-coded affinity tag (ICAT) tandem mass spectrometry (MS) for qualitative and quantitative analysis of tumour specific proteins in NAF, identified 353 peptides from 39 proteins in NAF samples from 18 women with breast cancer and 4 healthy volunteers. Alpha-2-HS-glyoprotein, was found to be decreased, whereas lipophilin B, betaglobin, hemopexin and vitamin-D binding protein were increased in breast cancer NAF samples. A recent study on six NAF samples ( 3 healthy individuals and 3 cancer patients) analysed by using an LTQ-Orbitrap XL mass spectrometer, identified more than 854 unique proteins, including established putative breast cancer biomarkers candidates, cancer antigen 15.3, tissue plasminogen activator, uPA, and cathepsin D [119]. Recently, in 
a series of experiments to optimise protein separation from a NAF sample, Brunoro et al. identified 557 different proteins [120]. The most complete proteomics study was performed by Shaheed et al. [121], identifying more than 1900 unique gene products including mitogenic growth factors (IGF1, IGF2, EGF, PDGFC, PGGFD, TGF $\beta 1$, VEGFA), cell adhesion proteins (CEACAMs, NCAM2, ICAM1), established breast cancer biomarkers (EGFR, mucin-1/CA 15-3, mucin-16/CA-125, MUCL1, cytokeratins $5,8,14$ and 18 ) as well as 46 candidate biomarkers under investigation by the National Cancer Institute Early Detection Research Network [122]. A comparison of matched NAF pairs, from a healthy volunteer and patients with benign, DCIS or invasive carcinoma, detected an average of more than 1200 proteins per sample [121]. While matched pairs exhibited strong similarity in profile, individuals showed significant differences, confirming the observations by Brunoro et al., using SDS PAGE and 2D-DIGE analysis of NAF [123]. Indeed, the composition of the healthy volunteer samples were disproportionately high in milk proteins, despite the fact that the subject had never breast fed. In this case, milk proteins were diagnostic for galactorrhea caused by prescribed medication inducing a nipple discharge [121]. The different protein profiles identified in NAF samples, collected by different groups, clearly highlight the potential for identifying biomarkers that could be related to the early development of breast cancer.

\section{Conclusions}

One of the major causes of death among women throughout the world is breast cancer. Despite tremendous progress in understanding the causes and advances in treatment regimens, the options for women at high risk of breast cancer are limited to drastic surgical intervention, because current methods for regular screening have significant limitations. Identifying biomarkers indicative of the earliest stages of malignancy has great potential, but so far it has not been fully explored. Cancer associated tissues are not readily accessible on a regular basis and plasma dilutes biomarkers once released from the diseased area. There would be huge benefits in analysing a biofluid collected from healthy volunteers and breast cancer patients that directly originates from the affected organ source. In this respect, NAF-based biomarkers offer great potential for developing an innovative noninvasive, patient-led screening strategy. NAF has multiple advantages as a liquid biopsy for detection of breast cancer: (1) premenopausal women, for whom current diagnostic modalities are limiting, are more likely to produce NAF than postmenopausal women where ductal atrophy is prevalent, (2) NAF production is non-invasive and causes less discomfort compared to other breast cancer screening procedures [124-126], (3) obtaining matched pairs of samples provides an "internal" control for comparing disease with healthy, (4) NAF is produced in close proximity to the cells lining the ducts, which are associated with $85 \%$ of all breast malignancies, and as a consequence is symptomatic of breast health, (5) biomarkers remain highly concentrated for analysis (compared to blood and urine where massive dilution significantly reduce detection sensitivity for tissue-derived proteins), and (6) sample preparation is reduced compared to tissues, which require yield-reducing protein extraction steps. NAF volumes are small, but protein concentrations are very high and are more than adequate for replicate analyses with state-of-the-art mass spectrometric techniques.

In a study of matched pairs of NAF samples by multiple reaction monitoring mass spectrometry (MRM MS), significant differences in prolactin inducible protein were observed between the diseased breast and the contralateral healthy breast (Fig. 1). With an MRM MS approach there is the potential to develop a multiplexed assay that measures a number of markers of breast health, defining patient-specific composition, that can be monitored in a longitudinal study. A wider study of a panel of biomarkers will provide increased specificity and would enable development of a clinical assay. This would provide high-risk women with a safe, convenient breast cancer detection program, which could be applied regularly to breast health surveillance, detect the earliest stages of the disease and avoid extreme preventative intervention procedures, such as elective bilateral mastectomy. Ultimately, detection of biomarkers in NAF could represent a paradigm shift in breast cancer management empowering women to express samples at home on a monthly or quarterly basis and analyse their own samples with a diagnostic kit, massively reducing the burden on health services (Fig. 2). 


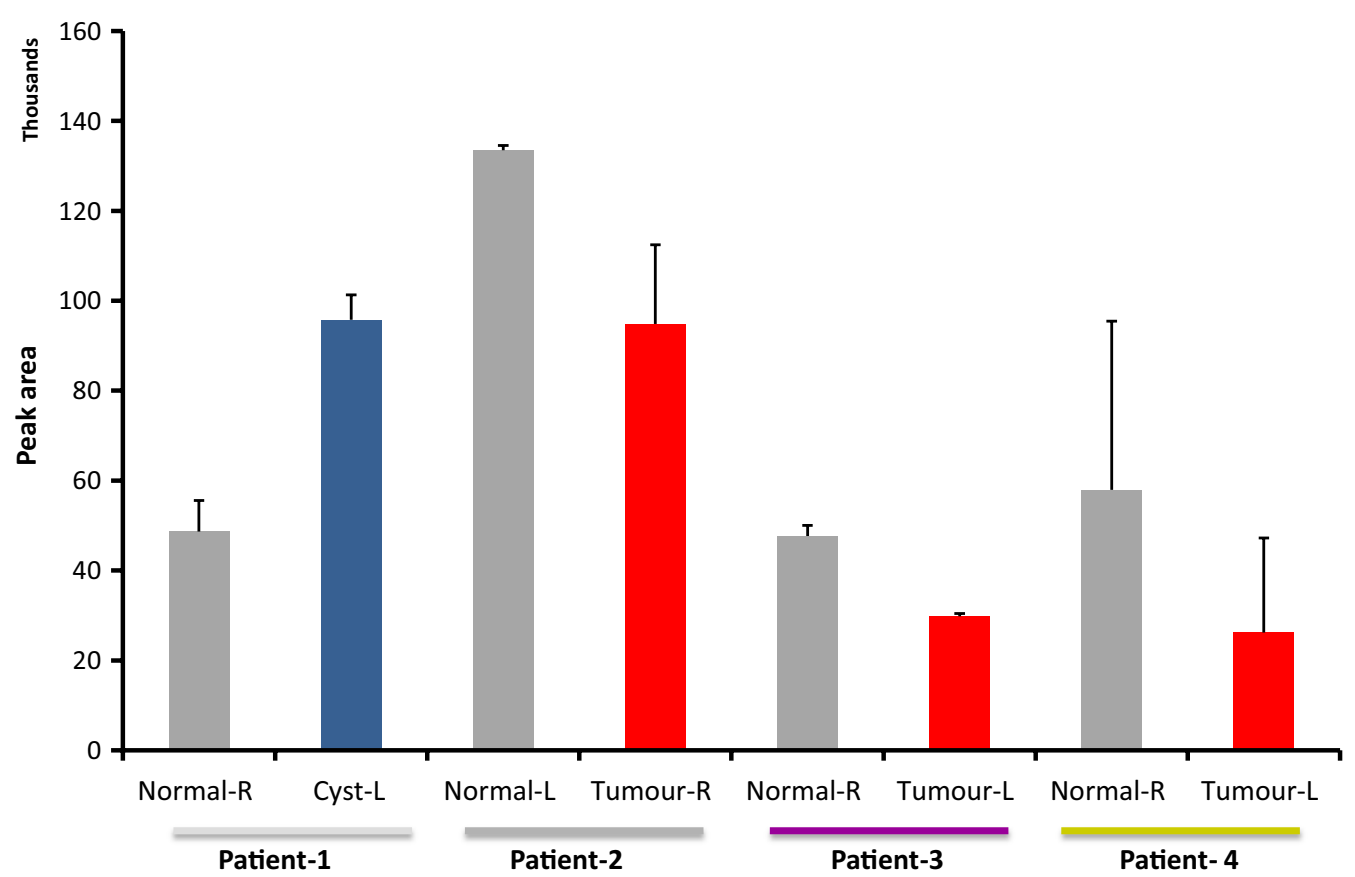

Fig. 1 Multiple reaction monitoring mass spectrometry analysis $(n=3)$ of a proteotypic peptide of prolactin inducible protein in matched NAF samples from four patients

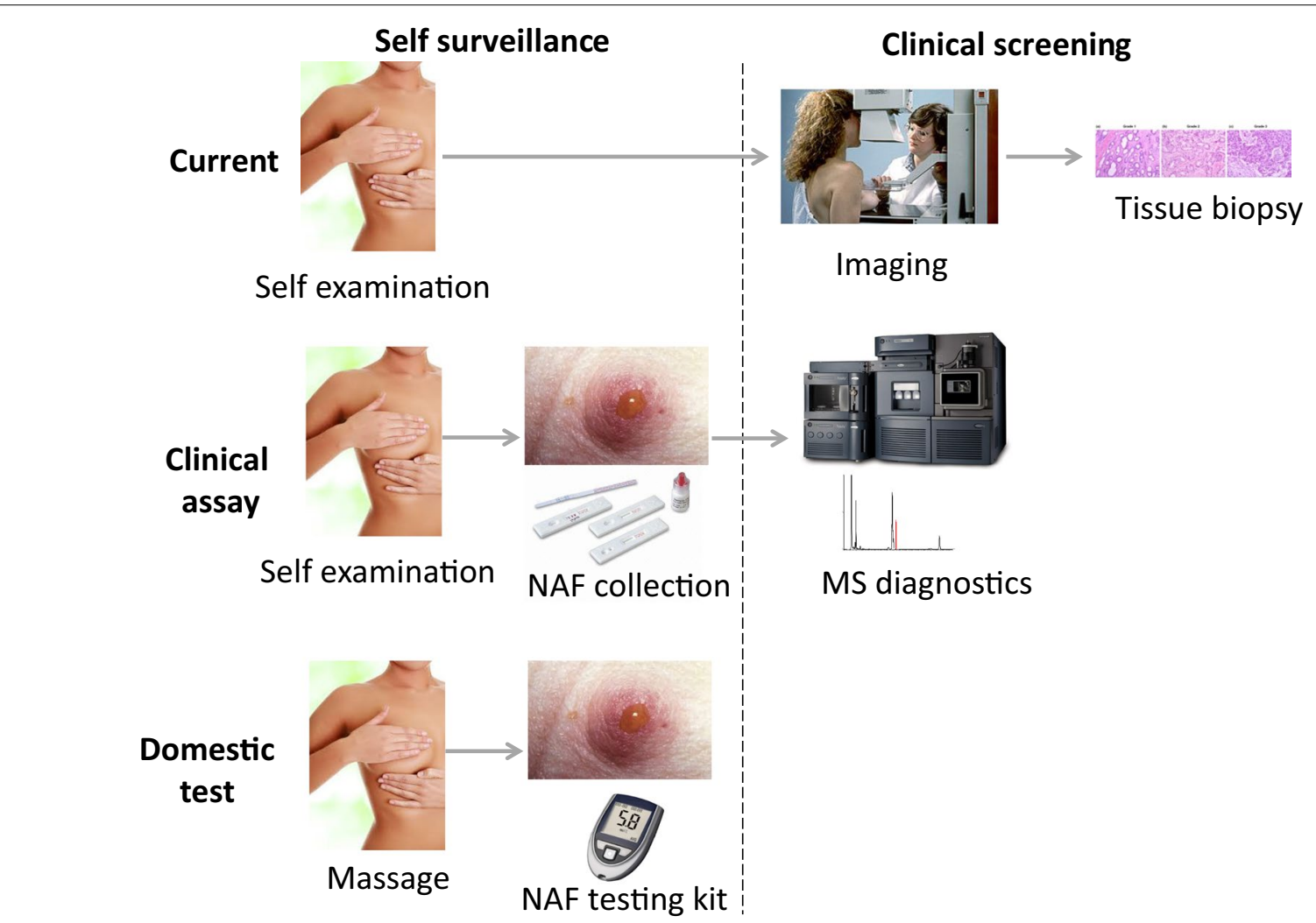

Fig. 2 Paradigm shift in breast cancer detection 


\begin{abstract}
Abbreviations
CRP: C-reactive; DBL: digital breast tomosynthesis; DCIS: ductal carcinoma in situ; DIGE: difference gel electrophoresis; DL: ductal lavage; ER: estrogen receptor; FDG: fluorodeoxyglucose; FTN: ferritin; HER2: human epidermal growth factor receptor 2; LC MS: 2D liquid chromatography mass spectrometry; MRI: magnetic resonance imaging; MRM MS: multiple reaction monitoring mass spectrometry; NAF: nipple aspirate fluid; PAl-1: plasminogen activator inhibitor 1; PET-CT: positron emission tomography with computer tomography; PR: progesterone receptor; PSA: prostate specific antigen; QTOF: quadrupole time-of-flight; ROC: receiver operating characteristics; RPFNA: Random Peri-areolar Fine Needle Aspiration; SOD-1: superoxide dismutase [Cu-Zn]; TF: transferrin; TFr: Thomsen-Friedenreich antigen; TNBC: triple negative breast cancers; UPA: urokinase-type plasminogen activator.
\end{abstract}

\section{Authors' contributions}

MS, CT and RL provided the evaluation of current breast cancer screening and imaging methods. SS, KK and CS provide the review of breast liquid biopsies. All authors read and approved the final manuscript.

\section{Authors' information}

MS and CT are Consultant Oncoplastic Breast Surgeons at the Bradford Teaching Hospitals NHS. RL is a Consultant Oncoplastic Breast Surgeon at the Bradford Teaching Hospitals NHS and a National trainer in Breast reconstruction (Onco-plastics) for the Association of Breast Surgeons of Great Britain. KK is the Head of Pathology at the Cyprus Institute of Neurology and Genetics. SS is a Postdoctoral Researcher studying breast cancer tissue and liquid biopsy proteomics at the Institute of Cancer Therapeutics (ICT) in the University of Bradford. CS is a Senior Lecturer in Proteomics and Mass Spectrometry at ICT, specialising in biomarker discovery for the early detection of cancer, and a Director of the British Society of Proteomics Research.

\section{Author details}

${ }^{1}$ Institute of Cancer Therapeutics, University of Bradford, Bradford, UK. ${ }^{2}$ Bradford Teaching Hospitals NHS Trust, Bradford, UK. ${ }^{3}$ The Cyprus School of Molecular Medicine, The Cyprus Institute of Neurology and Genetics, Nicosia, Cyprus.

\section{Acknowledgements}

The authors would like to thank Professor Laurence Patterson of the Institute of Cancer Therapeutics for his constructive input.

\section{Competing interests}

The authors declare that there are no competing interests.

\section{Availability of data and materials}

The datasets analysed in this study are available from the corresponding author subject to reasonable request.

\section{Consent for publication}

Not applicable.

\section{Ethical approval and consent to participate}

All participants gave written informed consent to undergo bilateral nipple aspiration. The study protocol was approved by University of Bradford's Independent Scientific Advisory Committee (reference: application/13/051). Ethical approval was given by Leeds (East) Research Ethics Committee, reference 07/ H1306/98+5.

\section{Funding}

Proteomics research was supported by Yorkshire Cancer Research projects, BPP047 and B381PA, and co-funded by the European Regional Development Fund and the Republic of Cyprus through the Research Promotion Foundation projects YГEIA/BIOE/0311(BIE/07) and NEKYP/0311/17.

\section{Publisher's Note}

Springer Nature remains neutral with regard to jurisdictional claims in published maps and institutional affliations.
Received: 20 October 2017 Accepted: 22 December 2017

Published online: 11 January 2018

\section{References}

1. Ferlay J, Steliarova-Foucher E, Lortet-Tieulent J, Rosso S, Coebergh JW, Comber H, Forman D, Bray F. Cancer incidence and mortality patterns in Europe: estimates for 40 countries in 2012. Eur J Cancer. 2013;49(6):1374-403.

2. Jemal A, Bray F, Center MM, Ferlay J, Ward E, Forman D. Global cancer statistics. CA Cancer J Clin. 2011;61(2):69-90.

3. Franco-Marina F, Lazcano-Ponce E, Lopez-Carrillo L. Breast cancer mortality in Mexico: an age-period-cohort analysis. Salud Publica Mex. 2009;51(Suppl 2):s157-64.

4. Sighoko D, Bah E, Haukka J, McCormack VA, Aka EP, Bourgeois D, Autier P, Byrnes G, Curado MP, Hainaut P. Population-based breast (female) and cervix cancer rates in the Gambia: evidence of ethnicity-related variations. Int J Cancer. 2010;127(10):2248-56.

5. Gnerlich JL, Deshpande AD, Jeffe DB, Sweet A, White N, Margenthaler JA. Elevated breast cancer mortality in women younger than age 40 years compared with older women is attributed to poorer survival in early-stage disease. J Am Coll Surg. 2009;208(3):341-7.

6. Aloraifi F, McDevitt T, Martiniano R, McGreevy J, McLaughlin R, Egan CM, Cody N, Meany M, Kenny E, Green AJ, et al. Detection of novel germline mutations for breast cancer in non-BRCA1/2 families. FEBS J. 2015;282(17):3424-37.

7. Mavaddat N, Antoniou AC, Easton DF, Garcia-Closas M. Genetic susceptibility to breast cancer. Mol Oncol. 2010;4(3):174-91.

8. Collaborative Group on Hormonal Factors in Breast Cancer. Menarche, menopause, and breast cancer risk: individual participant meta-analysis, including 118964 women with breast cancer from 117 epidemiological studies. Lancet Oncol. 2012;13(11):1141-51.

9. MacMahon B, Cole P, Lin TM, Lowe CR, Mirra AP, Ravnihar B, Salber EJ, Valaoras VG, Yuasa S. Age at first birth and breast cancer risk. Bull World Health Organ. 1970;43(2):209-21.

10. Shapiro $S$, Strax $P$, Venet $L$, Fink R. The search for risk factors in breast cancer. Am J Public Health Nations Health. 1968;58(5):820-35.

11. Reaves DK, Ginsburg E, Bang JJ, Fleming JM. Persistent organic pollutants and obesity: are they potential mechanisms for breast cancer promotion? Endocr Relat Cancer. 2015;22(2):R69-86.

12. Trevino LS, Wang Q, Walker CL. Hypothesis: Activation of rapid signaling by environmental estrogens and epigenetic reprogramming in breast cancer. Reprod Toxicol. 2015;54:136-40.

13. Bandera EV, Maskarinec G, Romieu I, John EM. Racial and ethnic disparities in the impact of obesity on breast cancer risk and survival: a global perspective. Adv Nutr. 2015;6(6):803-19.

14. Terry MB, McDonald JA, Wu HC, Eng S, Santella RM. Epigenetic biomarkers of breast cancer risk: across the breast cancer prevention continuum. Adv Exp Med Biol. 2016;882:33-68.

15. Eccles SA, Aboagye EO, Ali S, Anderson AS, Armes J, Berditchevski F, Blaydes JP, Brennan K, Brown NJ, Bryant HE, et al. Critical research gaps and translational priorities for the successful prevention and treatment of breast cancer. Breast Cancer Res. 2013;15(5):R92.

16. Banys M, Hartkopf AD, Krawczyk N, Kaiser T, Meier-Stiegen F, Fehm T, Neubauer H. Dormancy in breast cancer. Breast Cancer (Dove Med Press). 2012;4:183-91.

17. Anderson WF, Rosenberg PS, Prat A, Perou CM, Sherman ME. How many etiological subtypes of breast cancer: two, three, four, or more? J Natl Cancer Inst. 2014;106(8):dju165.

18. Prat A, Perou CM. Mammary development meets cancer genomics. Nat Med. 2009;15(8):842-4.

19. Anders CK, Zagar TM, Carey LA. The management of early-stage and metastatic triple-negative breast cancer: a review. Hematol Oncol Clin North Am. 2013;27(4):737-49.

20. Turkoz FP, Solak M, Petekkaya I, Keskin O, Kertmen N, Sarici F, Arik Z, Babacan T, Ozisik Y, Altundag K. The prognostic impact of obesity on 
molecular subtypes of breast cancer in premenopausal women.. BUON. 2013;18(2):335-41.

21. Güth U, Huang DJ, Huber M, Schötzau A, Wruk D, Holzgreve W, Wight E, Zanetti-Dällenbach R. Tumor size and detection in breast cancer: selfexamination and clinical breast examination are at their limit. Cancer Detect Prev. 2008;32(3):224-8.

22. Lechner L, De Nooijer J, De Vries H. Breast self-examination: longitudinal predictors of intention and subsequent behaviour. Eur I Cancer Prev. 2004;13(5):369-76.

23. Drukteinis JS, Mooney BP, Flowers Cl, Gatenby RA. Beyond mammography: new frontiers in breast cancer screening. Am J Med. 2013;126(6):472-9.

24. DeSantis C, Siegel R, Bandi P, Jemal A. Breast cancer statistics, 2011. CA Cancer J Clin. 2011;61(6):409-18.

25. Stout NK, Lee SJ, Schechter CB, Kerlikowske K, Alagoz O, Berry D, Buist DS, Cevik M, Chisholm G, de Koning HJ, et al. Benefits, harms, and costs for breast cancer screening after US implementation of digital mammography. J Natl Cancer Inst. 2014;106(6):dju092.

26. Loberg M, Lousdal ML, Bretthauer M, Kalager M. Benefits and harms of mammography screening. Breast Cancer Res. 2015;17:63.

27. Gotzsche PC, Jorgensen KJ. Screening for breast cancer with mammography. Cochrane Database Syst Rev. 1877;2013:CD001877.

28. Nelson HD, Tyne K, Naik A, Bougatsos C, Chan BK, Humphrey L, Force USPST. Screening for breast cancer: an update for the U.S. Preventive Services Task Force. Ann Intern Med. 2009;151(10):727-37 (W237-742).

29. Mushlin Al, Kouides RW, Shapiro DE. Estimating the accuracy of screening mammography: a meta-analysis. Am J Prev Med. 1998;14(2):143-53.

30. Johns LE, Moss SM, Age Trial Management Group. False-positive results in the randomized controlled trial of mammographic screening from age 40 ("Age" trial). Cancer Epidemiol Biomarkers Prev. 2010;19(11):2758-64.

31. Moss SM, Cuckle H, Evans A, Johns L, Waller M, Bobrow L, Trial Management $\mathrm{G}$. Effect of mammographic screening from age 40 years on breast cancer mortality at 10 years' follow-up: a randomised controlled trial. Lancet. 2006;368(9552):2053-60.

32. Obenauer S, Luftner-Nagel S, von Heyden D, Munzel U, Baum F, Grabbe E. Screen film vs full-field digital mammography: image quality, detectability and characterization of lesions. Eur Radiol. 2002;12(7):1697-702.

33. Pisano ED, Gatsonis C, Hendrick E, Yaffe M, Baum JK, Acharyya S, Conant EF, Fajardo LL, Bassett L, D'Orsi C, et al. Diagnostic performance of digital versus film mammography for breast-cancer screening. N Engl J Med. 2005;353(17):1773-83.

34. Espina V, Liotta LA. What is the malignant nature of human ductal carcinoma in situ? Nat Rev Cancer. 2011;11(1):68-75.

35. Francis A, Thomas J, Fallowfield L, Wallis M, Bartlett JM, Brookes C, Roberts T, Pirrie S, Gaunt C, Young J, et al. Addressing overtreatment of screen detected DCIS; the LORIS trial. Eur J Cancer. 2015;51(16):2296-303

36. Martin LJ, Boyd NF. Mammographic density. Potential mechanisms of breast cancer risk associated with mammographic density: hypotheses based on epidemiological evidence. Breast Cancer Res. 2008;10(1):201.

37. Vachon CM, Brandt KR, Ghosh K, Scott CG, Maloney SD, Carston MJ, Pankratz VS, Sellers TA. Mammographic breast density as a general marker of breast cancer risk. Cancer Epidemiol Biomarkers Prev. 2007;16(1):43-9.

38. Yaffe MJ. Mammographic density. Measurement of mammographic density. Breast Cancer Res. 2008;10(3):209.

39. Lei J, Yang P, Zhang L, Wang Y, Yang K. Diagnostic accuracy of digital breast tomosynthesis versus digital mammography for benign and malignant lesions in breasts: a meta-analysis. Eur Radiol. 2014;24(3):595-602.

40. Haas BM, Kalra V, Geisel J, Raghu M, Durand M, Philpotts LE. Comparison of tomosynthesis plus digital mammography and digital mammography alone for breast cancer screening. Radiology. 2013;269(3):694-700.

41. Giuliano V, Giuliano C. Improved breast cancer detection in asymptomatic women using 3D-automated breast ultrasound in mammographically dense breasts. Clin Imaging. 2013;37(3):480-6.

42. Warner E, Messersmith H, Causer P, Eisen A, Shumak R, Plewes D. Systematic review: using magnetic resonance imaging to screen women at high risk for breast cancer. Ann Intern Med. 2008;148(9):671-9.
43. Avril N, Rose CA, Schelling M, Dose J, Kuhn W, Bense S, Weber W, Ziegler S, Graeff H, Schwaiger M. Breast imaging with positron emission tomography and fluorine-18 fluorodeoxyglucose: use and limitations. J Clin Oncol. 2000;18(20):3495-502.

44. Schirrmeister H, Kuhn T, Guhlmann A, Santjohanser C, Horster T, Nussle K, Koretz K, Glatting G, Rieber A, Kreienberg R, et al. Fluorine-18 2-deoxy-2-fluoro-D-glucose PET in the preoperative staging of breast cancer: comparison with the standard staging procedures. Eur J Nucl Med. 2001;28(3):351-8.

45. Krouskop TA, Wheeler TM, Kallel F, Garra BS, Hall T. Elastic moduli of breast and prostate tissues under compression. Ultrason Imaging. 1998;20(4):260-74.

46. Hope TA, lles SE. Technology review: the use of electrical impedance scanning in the detection of breast cancer. Breast Cancer Res. 2004;6(2):69-74.

47. Salhab M, Keith LG, Laguens M, Reeves W, Mokbel K. The potential role of dynamic thermal analysis in breast cancer detection. Int Semin Surg Oncol. 2006:3:8.

48. Glas AM, Floore A, Delahaye LJ, Witteveen AT, Pover RC, Bakx N, LahtiDomenici JS, Bruinsma TJ, Warmoes MO, Bernards R, et al. Converting a breast cancer microarray signature into a high-throughput diagnostic test. BMC Genomic. 2006;7:278.

49. Yau C, Esserman L, Moore DH, Waldman F, Sninsky J, Benz CC. A multigene predictor of metastatic outcome in early stage hormone receptor-negative and triple-negative breast cancer. Breast Cancer Res. 2010;12(5):R85.

50. Cobleigh MA, Tabesh B, Bitterman P, Baker J, Cronin M, Liu ML, Borchik R, Mosquera JM, Walker MG, Shak S. Tumor gene expression and prognosis in breast cancer patients with 10 or more positive lymph nodes. Clin Cancer Res. 2005;11(24 Pt 1):8623-31.

51. Zhang Y, Sieuwerts AM, McGreevy M, Casey G, Cufer T, Paradiso A, Harbeck N, Span PN, Hicks DG, Crowe J, et al. The 76-gene signature defines high-risk patients that benefit from adjuvant tamoxifen therapy. Breast Cancer Res Treat. 2009;1 16(2):303-9.

52. Brooks M. Breast cancer screening and biomarkers. Methods Mol Biol. 2009:472:307-21.

53. Harris $L$, Fritsche $H$, Mennel $R$, Norton $L$, Ravdin $P$, Taube S, Somerfield MR, Hayes DF, Bast RC Jr. American Society of Clinical Oncology 2007 update of recommendations for the use of tumor markers in breast cancer. J Clin Oncol. 2007:25(33):5287-312.

54. Roncada P, Stipetic LH, Bonizzi L, Burchmore RJ, Kennedy MW. Proteomics as a tool to explore human milk in health and disease. J Proteomics. 2013;88:47-57.

55. Beck KL, Weber D, Phinney BS, Smilowitz JT, Hinde K, Lonnerdal B, Korf I, Lemay DG. Comparative proteomics of human and macaque milk reveals species-specific nutrition during postnatal development. J Proteome Res. 2015;14(5):2143-57.

56. Palmer DJ, Kelly VC, Smit AM, Kuy S, Knight CG, Cooper GJ. Human colostrum: identification of minor proteins in the aqueous phase by proteomics. Proteomics. 2006;6(7):2208-16.

57. Schneider SS, Aslebagh R, Ngounou Wetie AG, Sturgeon SR, Darie CC, Arcaro KF. Using breast milk to assess breast cancer risk: the role of mass spectrometry-based proteomics. Adv Exp Med Biol. 2014;806:399-408.

58. Celis JE, Gromova I, Gromov P, Moreira J, Cabezón T, Friis E, Rank F. Molecular pathology of breast apocrine carcinomas: a protein expression signature specific for benign apocrine metaplasia. FEBS Lett. 2006:580(12):2935-44.

59. Mannello F, Tonti GAM, Papa S. Human gross cyst breast disease and cystic fluid: bio-molecular, morphological, and clinical studies. Breast Cancer Res Treat. 2006:97(2):115-29.

60. Dooley WC, Ljung B-M, Veronesi U, Cazzaniga M, Elledge RM, O'Shaughnessy JA, Kuerer HM, Hung DT, Khan SA, Phillips RF. Ductal lavage for detection of cellular atypia in women at high risk for breast cancer. J Natl Cancer Inst. 2001;93(21):1624-32.

61. Khan SA, Wiley EL, Rodriguez N, Baird C, Ramakrishnan R, Nayar R, Bryk $M$, Bethke KB, Staradub VL, Wolfman J. Ductal lavage findings in women with known breast cancer undergoing mastectomy. J Natl Cancer Inst. 2004;96(20):1510-7.

62. Hartman AR, Daniel BL, Kurian AW, Mills MA, Nowels KW, Dirbas FM, Kingham KE, Chun NM, Herfkens RJ, Ford JM. Breast magnetic 
resonance image screening and ductal lavage in women at high genetic risk for breast carcinoma. Cancer. 2004;100(3):479-89.

63. Fackler MJ, Malone K, Zhang Z, Schilling E, Garrett-Mayer E, Swift-Scanlan T, Lange J, Nayar R, Davidson NE, Khan SA. Quantitative multiplex methylation-specific PCR analysis doubles detection of tumor cells in breast ductal fluid. Clin Cancer Res. 2006;12(11):3306-10.

64. Khan SA, Lankes HA, Patil DB, Bryk M, Hou N, Ivancic D, Nayar R, Masood S, Rademaker A. Ductal lavage is an inefficient method of biomarker measurement in high-risk women. Cancer Prev Res (Phila). 2009;2(3):265-73.

65. Danforth DN, Warner AC, Wangsa D, Ried T, Duelli D, Filie AC, Prindiville SA. An improved breast epithelial sampling method for molecular profiling and biomarker analysis in women at risk for breast cancer. Breast Cancer. 2015;9:31-40

66. Do Canto LM, Marian C, Willey S, Sidawy M, Da Cunha PA, Rone JD, Li X, Gusev Y, Haddad BR. MicroRNA analysis of breast ductal fluid in breast cancer patients. Int J Oncol. 2016;48(5):2071-8.

67. Do Canto LM, Marian C, Varghese RS, Ahn J, Da Cunha PA, Willey S, Sidawy M, Rone JD, Cheema AK, Luta G, et al. Metabolomic profiling of breast tumors using ductal fluid. Int J Oncol. 2016:49(6):2245-54.

68. Hoffman A, Pellenberg R, Drendall Cl, Seewaldt V. Comparison of random periareolar fine needle aspirate versus ductal lavage for risk assessment and prevention of breast cancer. Curr Breast Cancer Rep 2012:4(3):180-7.

69. Fabian CJ, Zalles C, Kamel S, Kimler BF, McKittrick R, Tranin AS, Zeiger S, Moore WP, Hassanein RS, Simon C, et al. Prevalence of aneuploidy, overexpressed ER, and overexpressed EGFR in random breast aspirates of women at high and low risk for breast cancer. Breast Cancer Res Treat. 1994:30(3):263-74.

70. Fabian CJ, Kimler BF, Zalles CM, Klemp JR, Kamel S, Zeiger S, Mayo MS. Short-term breast cancer prediction by random periareolar fineneedle aspiration cytology and the Gail risk model. J Natl Cancer Inst. 2000;92(15):1217-27.

71. Zalles C, Kimler BF, Kamel S, McKittrick R, Fabian CJ. Cytology patterns in random aspirates from women at high and low risk for breast cancer. Breast J. 1995;1 (6):343-9.

72. Fabian CJ, Kimler BF, Brady DA, Mayo MS, Chang CJ, Ferraro JA, Zalles CM, Stanton AL, Masood S, Grizzle WE. A phase II breast cancer chemoprevention trial of oral a-difluoromethylornithine breast tissue, imaging, and serum and urine biomarkers. Clin Cancer Res. 2002:8(10):3105-17.

73. Ibarra-Drendall C, Troch MM, Barry WT, Broadwater G, Petricoin EF III, Wulfkuhle J, Liotta LA, Lem S, Baker JC Jr, Ford AC. Pilot and feasibility study: prospective proteomic profiling of mammary epithelial cells from high-risk women provides evidence of activation of pro-survival pathways. Breast Cancer Res Treat. 2012;132(2):487-98.

74. Petrakis NL. Nipple aspirate fluid in epidemiologic studies of breast disease. Epidemiol Rev. 1993;15(1):188-95.

75. Sauter ER. Analysis of nipple aspirate fluid for diagnosis of breast cancer: an alternative to invasive biopsy. Expert Rev Mol Diagn. 2005;5(6):873-81.

76. Mannello F, Ligi D. Resolving breast cancer heterogeneity by searching reliable protein cancer biomarkers in the breast fluid secretome. BMC Cancer. 2013;13(1):344.

77. Fabian CJ, Kimler BF, Mayo MS, Khan SA. Breast-tissue sampling for risk assessment and prevention. Endocr Relat Cancer. 2005;12(2):185-213.

78. Mannello F. New horizon for breast cancer biomarker discoveries: What might the liquid biopsy of nipple aspirate fluid hold? Proteomics Clin Appl. 2017;11(9-10):1700015. https://doi.org/10.1002/prca.201700060

79. Petrakis NL. Physiologic, biochemical, and cytologic aspects of nipple aspirate fluid. Breast Cancer Res Treat. 1986;8(1):7-19.

80. Zhao Y, Pang D, Wang F, Xue Y, Gao D, Li H, Li K, Wang B, Wang D, Li H. Nipple aspirate fluid collection, related factors and relationship between carcinoembryonic antigen in nipple aspirate fluid and breast diseases in women in Harbin, PRC. Cancer Epidemiol Biomarkers Prev. 2009;18(3):732-8.

81. Hawke M. Update on cerumen and ceruminolytics. Ear Nose Throat J. 2002;81 (8 Suppl 1):23-4.

82. Sauter ER, Ross E, Daly M, Klein-Szanto A, Engstrom PF, Sorling A Malick J, Ehya H. Nipple aspirate fluid: a promising non-invasive method to identify cellular markers of breast cancer risk. $\mathrm{Br} J$ Cancer. 1997;76(4):494-501.
83. Zhang L, Shao ZM, Beatty P, Sartippour M, Wang HJ, Elashoff R, Chang $\mathrm{H}$, Brooks MN. The use of oxytocin in nipple fluid aspiration. Breast J. 2003;9(4):266-8.

84. Hornberger J, Chen SC, Li Q, Kakad P, Quay SC. Proliferative epithelial disease identified in nipple aspirate fluid and risk of developing breast cancer: a systematic review. Curr Med Res Opin. 2015;31 (2):253-62.

85. Mannello F, Tonti GA, Qin W, Zhu W, Sauter ER. Do nipple aspirate fluid epithelial cells and their morphology predict breast cancer development? Breast Cancer Res Treat. 2007;102(1):125-7.

86. Malatesta M, Mannello F, Bianchi G, Sebastiani M, Gazzanelli G. Biochemical and ultrastructural features of human milk and nipple aspirate fluids. J Clin Lab Anal. 2000;14(6):330-5.

87. Sartorius O. Breast fluid cells help in early cancer detection. JAMA. 1973;224:823-7.

88. Petrakis N, Lee R, Miike R, Dupuy M, Morris M. Coloration of breast fluid related to concentration of cholesterol, cholesterol epoxides, estrogen, and lipid peroxides. Am J Clin Pathol. 1988;89(1):117-20.

89. Chan AA, Bashir M, Rivas MN, Duvall K, Sieling PA, Pieber TR, Vaishampayan PA, Love SM, Lee DJ. Characterization of the microbiome of nipple aspirate fluid of breast cancer survivors. Sci Rep. 2016;6:28061.

90. Dietz JR, Crowe JP, Grundfest S, Arrigain S, Kim JA. Directed duct excision by using mammary ductoscopy in patients with pathologic nipple discharge. Surgery. 2002;132(4):582-8.

91. Sauter ER, Winn JN, Dale PS, Wagner-Mann C. Nipple aspirate fluid color is associated with breast cancer. Cancer Detect Prev. 2006;30(4):322-8.

92. Lee MM, Wrensch MR, Miike R, Petrakis N. The association of dietary fat with ability to obtain breast fluid by nipple aspiration. Cancer Epidemiol Biomarkers Prev. 1992; (4):277-80.

93. Huang Y, Anderson KE, Nagamani M, Grady JJ, Lu L-JW. Dietary intake of lactose as a strong predictor for secretor status of nipple aspirate fluid in healthy premenopausal nonlactating women. Clin Cancer Res. 2008;14(5):1386-92

94. Maskarinec G, Ollberding NJ, Conroy SM, Morimoto Y, Pagano IS, Franke AA, Gentzschein E, Stanczyk FZ. Estrogen levels in nipple aspirate fluid and serum during a randomized soy trial. Cancer Epidemiol Biomarkers Prev. 2011;20(9):1815-21.

95. Djuric Z, Ren J, Mekhovich O, Venkatranamoorthy R, Heilbrun LK. Effects of high fruit-vegetable and/or low-fat intervention on plasma micronutrient levels. J Am Coll Nutr. 2006;25(3):178-87.

96. Maskarinec G, Hebshi S, Custer L, Franke AA. The relation of soy intake and isoflavone levels in nipple aspirate fluid. Eur J Cancer Prev. 2008:17(1):67-70.

97. Sauter E, Ehya H, Babb J, Diamandis E, Daly M, Klein-Szanto A, Sigurdson E, Hoffman J, Malick J, Engstrom P. Biologic markers of risk in nipple aspirate fluid are associated with residual cancer and tumour size. $\mathrm{Br} J$ Cancer. 1999:81(7):1222.

98. Sauter ER, Tichansky DS, Chervoneva I, Diamandis EP. Circulating testosterone and prostate-specific antigen in nipple aspirate fluid and tissue are associated with breast cancer. Environ Health Perspect. 2002;110(3):241.

99. Kumar SR, Sauter ER, Quinn TP, Deutscher SL. Thomsen-Friedenreich and Tn antigens in nipple fluid: carbohydrate biomarkers for breast cancer detection. Clin Cancer Res. 2005;11(19 Pt 1):6868-71.

100. Deutscher SL, Dickerson M, Gui G, Newton J, Holm JE, Vogeltanz-Holm N, Kliethermes B, Hewett JE, Kumar SR, Quinn TP. Carbohydrate antigens in nipple aspirate fluid predict the presence of atypia and cancer in women requiring diagnostic breast biopsy. BMC Cancer. 2010;10(1):519.

101. Djuric Z, Visscher DW, Heilbrun LK, Chen G, Atkins M, Covington CY. Influence of lactation history on breast nipple aspirate fluid yields and fluid composition. Breast J. 2005;11(2):92-9.

102. Mannello F, Malatesta M, Sebastiani M, Battistelli S, Gazzanelli G. Molecular forms and ultrastructural localization of prostate-specific antigen in nipple aspirate fluids. Clin Chem. 1999;45(12):2263-6.

103. Sauter ER, Daly M, Linahan K, Ehya H, Engstrom PF, Bonney G, Ross EA, Yu H, Diamandis E. Prostate-specific antigen levels in nipple aspirate fluid correlate with breast cancer risk. Cancer Epidemiol Biomarkers Prev. 1996;5(12):967-70

104. Sauter ER, Klein G, Wagner-Mann C, Diamandis EP. Prostate-specific antigen expression in nipple aspirate fluid is associated with advanced breast cancer. Cancer Detect Prev. 2004;28(1):27-31. 
105. Mannello F, Tonti GA, Pederzoli A, Simone P, Smaniotto A, Medda V. Detection of Superoxide dismutase-1 in nipple aspirate fluids: a reactive oxygen species - regulating enzyme in the breast cancer microenvironment. clin breast cancer. 2010;10(3):238-45.

106. Oda M, Makita M, Iwaya K, Akiyama F, Kohno N, Tsuchiya B, Iwase T, Matsubara O. High levels of DJ-1 protein in nipple fluid of patients with breast cancer. Cancer Sci. 2012;103(6):1172-6.

107. Mannello F, Ligi D, Canale M. Aluminium, carbonyls and cytokines in human nipple aspirate fluids: Possible relationship between inflammation, oxidative stress and breast cancer microenvironment. J Inorg Biochem. 2013:128:250-6.

108. Kabat GC, Rohan TE. Does excess iron play a role in breast carcinogenesis? An unresolved hypothesis. Cancer Causes Control. 2007;18(10):1047-53.

109. Mannello F, Tonti GA, Medda V, Simone P, Darbre PD. Analysis of aluminium content and iron homeostasis in nipple aspirate fluids from healthy women and breast cancer-affected patients. J Appl Toxicol. 2011;31(3):262-9.

110. Duffy MJ. Urokinase plasminogen activator and its inhibitor, PAl-1, as prognostic markers in breast cancer: from pilot to level 1 evidence studies. Clin Chem. 2002;48(8):1194-7.

111. Qin W, Gui G, Zhang K, Twelves D, Kliethermes B, Sauter ER. Proteins and carbohydrates in nipple aspirate fluid predict the presence of atypia and cancer in women requiring diagnostic breast biopsy. BMC Cancer. 2012;12(1):52

112. Robertson J, Pearson D, Price M, Selby C, Pearson J, Blamey R, Howell A. Prospective assessment of the role of five tumour markers in breast cancer. Cancer Immunol Immunother. 1991;33(6):403-10.

113. Lithgow D, Nyamathi A, Elashoff D, Martinez-Maza O, Covington C. C-reactive protein in nipple aspirate fluid associated with Gail model factors. Biol Res Nurs. 2007;9(2):108-16.

114. Mannello F, Medda V, Tonti GA. Protein profile analysis of the breast microenvironment to differentiate healthy women from breast cancer patients. Expert Rev Proteomics. 2009;6(1):43-60.

115. Paweletz CP, Trock B, Pennanen M, Tsangaris T, Magnant C, Liotta LA, Petricoin lii EF. Proteomic patterns of nipple aspirate fluids obtained by SELDI-TOF: potential for new biomarkers to aid in the diagnosis of breast cancer. Dis Markers. 2001;17(4):301-7.

116. Varnum SM, Covington CC, Woodbury RL, Petritis K, Kangas LJ, Abdullah MS, Pounds JG, Smith RD, Zangar RC. Proteomic characterization of nipple aspirate fluid: identification of potential biomarkers of breast cancer. Breast Cancer Res Treat. 2003:80(1):87-97.

117. Alexander H, Stegner AL, Wagner-Mann C, Du Bois GC, Alexander S, Sauter ER. Proteomic analysis to identify breast cancer biomarkers in nipple aspirate fluid. Clin Cancer Res. 2004;10(22):7500-10.

118. PawlikTM, Hawke DH, Liu Y, Krishnamurthy S, Fritsche H, Hunt KK, Kuerer HM. Proteomic analysis of nipple aspirate fluid from women with early-stage breast cancer using isotope-coded affinity tags and tandem mass spectrometry reveals differential expression of vitamin D binding protein. BMC Cancer. 2006;6(1):68.

119. Pavlou MP, Kulasingam V, Sauter ER, Kliethermes B, Diamandis EP. Nipple aspirate fluid proteome of healthy females and patients with breast cancer. Clin Chem. 2010;56(5):848-55.

120. Brunoro GV, Carvalho PC, Ferreira AT, Perales J, Valente RH, de Moura Gallo CV, Pagnoncelli D, Neves-Ferreira AG. Proteomic profiling of nipple aspirate fluid (NAF): exploring the complementarity of different peptide fractionation strategies. J Proteomics. 2015;117:86-94.

121. Shaheed SU, Tait C, Kyriacou K, Mullarkey J, Burrill W, Patterson LH, Linforth R, Salhab M, Sutton CW. Nipple aspirate fluid-a liquid biopsy for diagnosing breast health. Proteomics Clin Appl. 2017;11(9-10):1700015. https://doi.org/10.1002/prca.201700015.

122. Srivastava S, Patriotis C. Systematic, evidence-based discovery of biomarkers at the National Cancer Institute. Int J Gynecol Cancer. 2012;22(Suppl 1):S41.

123. Brunoro GV, Ferreira AT, Trugilho MR, Oliveira TS, Amendola LC, Perales J, Valente RH, Gallo CV, Pagnoncelli D, Neves-Ferreira AG. Potential correlation between tumor aggressiveness and protein expression patterns of nipple aspirate fluid (NAF) revealed by gel-based proteomic analysis. Curr Top Med Chem. 2014;14(3):359-68.

124. Klein P, Glaser E, Grogan L, Keane M, Lipkowitz S, Soballe P, Brooks L, Jenkins J, Steinberg SM, DeMarini DM, et al. Biomarker assays in nipple aspirate fluid. Breast J. 2001;7(6):378-87.

125. Suijkerbuijk KP, van der Wall $E$, Meijrink $H$, Pan $X$, Borel Rinkes $I H$, Ausems MG, van Diest PJ. Successful oxytocin-assisted nipple aspiration in women at increased risk for breast cancer. Fam Cancer. 2010;9(3):321-5.

126. Loud JT, Beckjord EB, Nichols K, Peters J, Giusti R, Greene MH. Tolerability of breast ductal lavage in women from families at high genetic risk of breast cancer. BMC Womens Health. 2009;9:20.

\section{Submit your next manuscript to BioMed Central and we will help you at every step:}

- We accept pre-submission inquiries

- Our selector tool helps you to find the most relevant journal

- We provide round the clock customer support

- Convenient online submission

- Thorough peer review

- Inclusion in PubMed and all major indexing services

- Maximum visibility for your research

Submit your manuscript at www.biomedcentral.com/submit
O Biomed Central 